\title{
Biomechanical tests: applications and their reliability for the prediction of bone strength in broiler chicken
}

\author{
Komal Khan ${ }^{1}$, Figen Sevil Kilimci², Mehmet Erkut Kara ${ }^{2}$ \\ ${ }^{1}$ Anatomy and Histology Department, Faculty of Veterinary Sciences, University of Veterinary and Animal Sciences, Lahore/PAKISTAN \\ ${ }^{2}$ Anatomy Department, Veterinary Faculty, Adnan Menderes University, Aydin/TURKEY
}

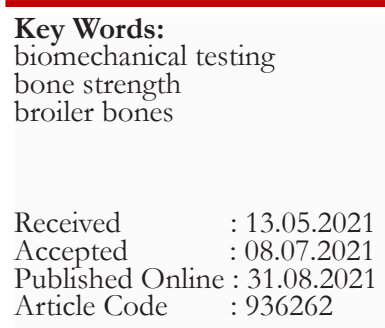

Correspondence:

K. KHAN

(email: komal.khan@uvas.edu.pk)

\section{ORCID}

K. KHAN

: 0000-0002-0085-1812

F. SEVIL KILIMCI : 0000-0002-2291-0545

ME. KARA : :0000-0002-5056-1688

\begin{abstract}
The poultry industry is considered potent for the economy of any country because chicken production is an important food source now-a-days. However, skeletal abnormalities are one of the major contributing factors to production loss. For decades researchers are trying to make contributions for the diagnosis of these problems effectively and are giving suggestions for the improvement in their skeletal deficiencies. Bone structural and metabolic disturbances (like tibial dyschondroplasia, osteoporosis and osteoarthrosis) are common in broiler chickens and have emerged in past few years. Due to fast growth and high leg to body weight ratio bone suffers excessive stress and loses the strength. Such conditions are manifested with a tendency for fracture. Understanding of bone quality provides deep information of the mechanical and functional aspects of bone tissues. The measurements of the bone strength can be performed with some methods, like the geometrical indices, radiographic or dual-energy X-ray absorptiometric density measurements, ash content measurements or the assays of bone turnover biomarkers. But biomechanical tests are the core diagnostic tools that can measure bone health parameters with reliable indicators. In this review, an overview of the mechanical tests used to test bone quality has been given and the effectiveness of such methods is discussed using different bones of poultry birds. Knowing the basic concepts on biomechanical tests applied in poultry bones and comparing the results to identify suitable testing methods may input improvement in the dialogue between the researchers interested in the assessment of bone strength at both structural and pathophysiological levels.
\end{abstract}

\section{INTRODUCTION}

Similar to mammals, birds' bones play various functions, like support of the body mass, protection of the internal organs and provision of calcium (Ca) for eggshell formation (1). This Ca for egg production is an additional role which is affecting their bone quality. Moreover, birds' bones have attained structural variations for flight adaptation as well. Relative to the body weight, birds' skeleton is lighter than mammals as birds need to maintain balance and take glide due to light weight. For this purpose, several bones (e.g., humerus, coracoid, sternum, skull, pelvic girdle, lumbar and sacral vertebrae) have also acquired air-filled structures/sacs. Another variation can be seen in the form of having no true epiphyseal plate and skeletal maturity occurs relatively earlier in birds. This early matured skeleton helps them to take flight at smaller age. In animal kingdom, bone deposition begins at primary and secondary centres of ossification but only a few bones have secondary centres of ossification in birds (2). Only proximal (3) and distal tibia and proximal metatarsus have true bony epiphyses $(2,4)$. Another important feature is that the birds' bones are stronger and stiffer than the bones of the small mammals due to higher density (5).

Keeping these differences in mind, considerable research is going on to understand welfare problems of poultry birds such as leg pathologies affecting locomotion in chickens (6$9)$. Fast-growing broilers had better bone morphology and stronger bones than slow-growing genotype. Therefore, fastgrowing genotype can provide positive effects on bone growth and mechanical properties in broilers (10). For decades during genetic selection and changing rearing conditions to get good production, focus was mostly kept on high growth rates, meat and egg quality rather than bone quality and strength. It has produced some undesired consequences now-a-days, like weak bones and increase in susceptibility to fractures and many more skeletal disorders. There are some skeletal problems seen mostly in poultry i.e. long bone deformities, tibial dyschondroplasia, rickets, spondylolisthesis, degeneration of the femoral head, spraddled legs, chondrodystrophy, osteoporosis, arthritis, and footpad lesions $(11,12)$.

Both geometrical and mechanical properties of the bone play significant role in its quality (13) and are vital indicators of the bone status $(9,14)$. The mechanical properties of the bone are not only dependent on its mineralisation but are also subjective to its sponginess and matrix structuring. However, genetic selection on the basis of high production has resulted in change in the mechanical properties of the poultry bones since these are showing reduced strength due to less inorganic matter and more porosity (9). Bones differ greatly in the shape, size and strength among animal species (15). Bone strength depends on its geometry, cortical thickness, porosity and trabecular bone framework (16). If any of these features is lost, it can be fractured easily $(14,17)$. 
The DEXA (Dual energy X-ray absorptiometry) or some imaging techniques have been used to understand bone strength with measuring bone density (1, 18-28). The geometrical indices (the cortical indices, robusticiy index etc.) and ash content may also considered to assess bone strength $(16,29)$. Therefore, there are also various methodologies to assess mechanical integrity of bones but direct mechanical testing undoubtedly seems to be the best option (30-32). Besides, now-a-days, biomechanical tests are also performed to evaluate the mechanical properties of bones, estimating their strength and the breaking points after making them exposed to different nutritional trials to get better production in terms of meat and eggs.

\section{Suitable bones for biomechanical tests}

When we start to investigate the mechanical properties of the bone, we encounter a problem: at what level of investigation should we start? We can investigate single whole bone, piece of a bone, at histological level or even with an electron microscope upto collagen orientation to understand bone strength. The biomechanical tests are performed mostly on whole bones and less often on irregular shaped geometry, where a constant sized sample is taken out to test. Three- or four-point bending or torsional tests are mostly applied on long bones, whereas selected irregular bones like vertebral bone or cylindrical specimens extracted from a long bone are tested in compression method. Most often these loads are applied till fracture occurs $(33,34)$.

Although the aim of the study is an important factor to choose the technique of the mechanical testing, some studies offer different bones for different biomechanical testing methods. Harner and Wilson (30) found layers tibia less suitable for bending as it can rotate on load application while radius and femur are ideal bones for bending test in poultry due to straight and symmetrical geometry. The humerus seemed to be fitted for shear test application because its shear properties are less influenced by its geometry. Also the shear test can be applied to a bone even if it is having less than tenL/D (length to diameter) ratio. They also suggested torsional test is good for tibia and radius. Nonetheless, the femur is mostly prefered by the researchers for study because of its good accessibility during dissection. Massé et al. (35) while working on chick, on the contrary, said that tibia is better as it is more susceptible to mechanical stress and is rapidly growing bone. If this is so, then could be a better option because it is longest among long bones in poultry birds and unlike some other experimental animals, fibula can also be easily separated from tibia.

While going through available literature we observed that poultry tibiotarsus are mostly used to see long bones bending properties or mechanical strength of broiler bones.

\section{Prepartion of bones for biomechanical tests}

The bones are removed just after euthenasia, by gentle dissection to clean off the soft tissues but keeping periosteum intact, and used in fresh form (wrap them in sterile-soaked guaze and place them at $4^{\circ} \mathrm{C}$ for short duration). To keep them for long time, the bones should be wrapped in sterile saline-soaked gauze, sealed in air-tight plastic bags and stored at $-20^{\circ} \mathrm{C}$ until testing (36). Massé et al. (35) reported study on even $-70^{\circ} \mathrm{C}$ temperature which was also considered ideal by An \& Draughn (36). Although some researches used boiled, embalmed or autoclaved bones $(24,37)$, these methods are inappropriate for mechanical testing (36). Thawing step has no impact on biomechanical properties of bones and maintains wet condition $(14,35,38,39)$. Vaughan et al. (40) thawed femurs at $4^{\circ} \mathrm{C}$ and then slowly brought to $20^{\circ} \mathrm{C}$ before preparation for mechanical tests. So, there must be slow thawing. However, bones should not be kept at room tempearture for more than 12 hours (36). Later on, bone ends can be embedded in some materials before biomechanical tests, especially in the torsion test, to make a test more reliable by fixing the bone ends to the machine jaw. In such tests, holding the bone well in order to prevent slipping is required for trustworthy results. For this purpose, various materials such as polyester, polyurethane, polymethylmethacrylate (PMMA), wood metal, epoxy can be used. Among them, polyester potting is a cheap and easily available material $(36,41-43)$. The Figure 1 is showing steps which are performed before any mechanical test.

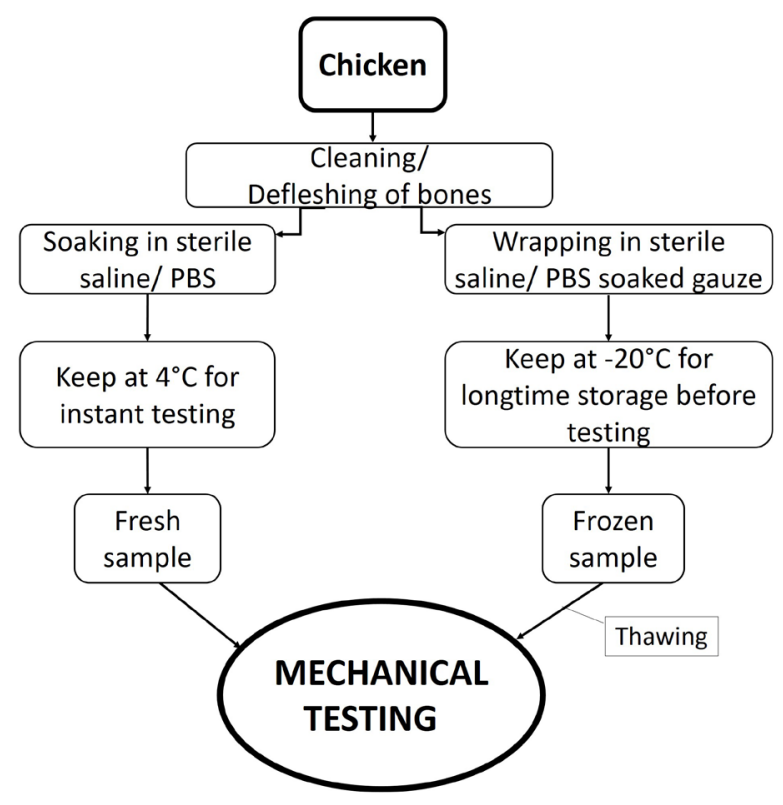

Figure 1. Flowchart describing the basic steps conducted before mechanical testing of the poultry bones

\section{Geometrical parameters for biomechanical tests}

For biometrical research, some geometrical prameters of the bone are obtained. The total length and cranio-caudal and medio-lateral diameters are measured with a caliper and bones mass are weighed on precision balance $(35,37)$. The exterior dimensions are taken at the center of the diaphysis before loading and the interior dimensions are recorded after failure. To get more precise measurements of these parameters, it is preferable to use modern techniques like CT, radiographs or stereomicroscopic images rather than manual method (4, 20, 44). 


\section{Loading Rate}

Besides the direction of the force applied to the bone, the application speed is also an important factor affecting the mechanical data. Because bone is a viscoelastic material whose mechanical properties can differ according to the rate of the applied force (36). Therefore, when planning the mechanical test, the speed at which the load will be applied should be determined in advance. As the mechanical properties of the bones are detected using standard load rates, already mentioned in the previous studies, the results of any study seem to be more appropriate for comparison with the aforementioned data.

In general, force is applied at a speed of $\square 1-100 \mathrm{~mm} / \mathrm{min}$ to simulate physiological conditions and $1-5 \mathrm{~m} / \mathrm{sec}$ for trauma and impact simulations $(32,36)$. According to the ASABE standards, a speed of $5 \mathrm{~mm} / \mathrm{min}$ for the shear test and 10 $\mathrm{mm} / \mathrm{min}$ for the bending test should be used for poultry bones (45). Besides, loading speeds in different poultry studies are indicated below.

\section{Biomechanical tests}

Before starting the mechanical test, firstly it is necessary to gather knowledge about the testing standards and literature published on this subject, and decide the test type (staticdynamic / compression, tension, torsion, etc.). Secondly, determine the laboratory in the surroundings where there are suitable testing machines, the suitability of the machine jaw according to the test to be performed there, the preparation of the necessary materials and a preliminary study.

Additionally, researchers should consider safety precautions before proceeding to the testing phase. Small bone fragments that are broken during test application can harm workers or biosecurity problems may be encountered due to handling of the organic materials.

There are different mechanical tests that are used to evaluate the biomechanical properties of poultry bones like bending, tension, compression, shear and torsional testing of bones (30, $46,47)$. It must be indicated that, the standard of American society of Agricultural and biological engineers offers at least 25 test specimens to perform a reliable study for the 3-point bending and sheer tests (45).

These mechanical testing methods of the bones has been discussed briefly in this review.

\section{Bending Tests}

The most common methods used to test whole bones are certainly bending tests. Bending cause tension on the convex side while compression on the concave side of the bone (36). These tests are used specifically to characterise the mechanical behaviour of bones (16, 48-52). The 3-point or 4-point bending experiments are in general practice (53). Three-point bending test is seen to be the most common among all the mechanical tests performed on the poultry bones so far. In contrast to engineering testing materials, the bones are having irregular surface geometry, that's why they are mostly tested in 3-point bending method.

In 3-point bending, a single-pronged loading device is applied at a point precisely in the middle between the two supports and the bone will ultimately fracture at this location because of the maximum load. This test is only applicable to bones having uniform cross-section with length to diameter ratio greater than 10 and a standard speed of $10 \mathrm{~mm} / \mathrm{min}$ should be preferred (45) in case of poultry bones. The prongs should be blunt and have about $4.0 \mathrm{~mm}$ radius each. Štofaníková et al. (14) found increased tibiotarsal bone strength in broilers fed with zinc diet, through three-point bending test. This test was used to find correlation of layers' tibial bone breaking force with other bone measurements (9). Even this test was applied on keel bone to determine its ultimate strength (54). This test was applied on femur to check Escherichia coli phytase administration on skeletal properties of turkeys, with loading rate $50 \mathrm{~mm} / \mathrm{min}$. (55). Shim et al. (56) used this test to check tibial breaking strength in fast and slow growing broilers while (27) checked strength of tibia in genetically selected laying hens and bone strength in autochtonous naked neck breeds of chickens (57).

The major difference between three-point and four-point bending is the construction of the loading-prongs. The load is applied by two loading prongs located equidistance from the mid point. The main advantage of this method is that the entire section of bone is under a uniform moment, and there is no shear. The two prongs are usually spaced such that the area of interest is located between them to ensure the uniformity of bending moment and the surfaces of bone in touch with prongs should be smooth. Data collection is same as for the three-point bending $(32,36,58)$. Karásek et al. (59) used to check broiler femur strength after calcium and magnicium supplementation.

In cantilever test, one end of the bone is freely movable while the other end is tightened firmly to some support. For this type of bending setup, the moment of inertia is found to be maximum at unmovable side and zero where the force is applied (36). Data is collected just like mentioned above for three-point testing of the bones. As far as our knowledge is concerned we could not find any study with this particular test on poultry bones.

\section{Shear test}

For pure shear test, a double shear block arrangement is considered an appropriate technique. The distance between each of the two lower supports and the shear loading prong shall not exceed $0.05 \mathrm{~mm}$ for poultry bones. The radii of curvature of the loading cell and lower sample supports should be adjusted according to the sample size (45). For the shear test, a speed of $5 \mathrm{~mm} / \mathrm{min}$ may be used for poultry otherwise, for example, Rowland \& Harms (60) have shown that lowering the loading rate will also lower the ultimate bending force in poultry bones (45). Liu et al. (61) performed shear test on tibia of quail with load rate of $2 \mathrm{~mm} / \mathrm{min}$. while (62) used $5 \mathrm{~mm} /$ min. load rate on tibia, femur, humerus and radius of layers. Buijs et al. (63) used Mecmesin BFG $200 \mathrm{~N}$ force gauge at a speed of $12 \mathrm{~mm} / \mathrm{min}$ on tibia of broilers. 
Tablo 1. Shows data obtained after biomechanical tests and calculations.

\begin{tabular}{|c|c|c|c|c|}
\hline Parameter & & Abbreviation & Unit & Description \\
\hline \multirow[t]{7}{*}{$\begin{array}{l}\text { Cross-Sectic } \\
\text { Geometric } \\
\text { Properties }\end{array}$} & $\begin{array}{l}\text { Inner diameter } \\
\text { (endosteal } \\
\text { diameter) }\end{array}$ & ID & $\mathrm{mm}$ & $\begin{array}{l}\text { Internal bone diameters in } \\
\text { mediolateral and cranio-caudal } \\
\text { directions. }\end{array}$ \\
\hline & $\begin{array}{l}\text { Outer diameter } \\
\text { (periosteal } \\
\text { diameter) }\end{array}$ & OD & $\mathrm{mm}$ & $\begin{array}{l}\text { External bone diameters in } \\
\text { mediolateral and cranio-caudal } \\
\text { directions. }\end{array}$ \\
\hline & Cortical thickness & Ct.Th & $\mathrm{mm}$ & $\begin{array}{l}\text { It is the thickness located betwe- } \\
\text { en the endosteum and the peri- } \\
\text { osteum. (Medial, lateral, cranial, } \\
\text { caudal direction). }\end{array}$ \\
\hline & Total Area & Tt.Ar & $\mathrm{mm}^{2}$ & $\begin{array}{l}\text { It is the area enclosed by the } \\
\text { periosteal surface. }\end{array}$ \\
\hline & Marrow Area & Ma.Ar & $\mathrm{mm}^{2}$ & $\begin{array}{l}\text { It is the area enclosed by the } \\
\text { endosteum. }\end{array}$ \\
\hline & Cortical Area & Ct.Ar & $\mathrm{mm}^{2}$ & $\begin{array}{l}\text { It is the area located between the } \\
\text { periosteum and the endosteum. } \\
\text { It is obtained by subtracting the } \\
\text { marrow area from the total area. }\end{array}$ \\
\hline & $\begin{array}{l}\text { Moment of } \\
\text { inertia }\end{array}$ & $\begin{array}{l}\mathrm{I}_{\mathrm{MAX}}, \mathrm{I}_{\mathrm{MIN}}, \mathrm{I}_{\mathrm{CRCD}}, \\
\mathrm{I}_{\mathrm{ML}}\end{array}$ & $\mathrm{mm}^{4}$ & $\begin{array}{l}\text { Moment of inertia describes } \\
\text { thegeometric contribution of } \\
\text { the bone in resisting bending } \\
\text { andtorsional loading. }\end{array}$ \\
\hline \multirow{4}{*}{$\begin{array}{l}\text { Whole-bone } \\
\text { mechanical } \\
\text { properties }\end{array}$} & Maximum load & $\mathrm{F}_{\mathrm{MAX}}$ & $\mathrm{N}$ & $\begin{array}{l}\text { It is simply the greatest load } \\
\text { endured before fracture. }\end{array}$ \\
\hline & Displacement & $\Delta \mathrm{s}$ & $\mathrm{mm}$ & $\begin{array}{l}\text { It shows the displacements that } \\
\text { occur when bone tissue is expo- } \\
\text { sed to higher levels of load. }\end{array}$ \\
\hline & Stiffness & K & $\mathrm{N} / \mathrm{mm}$ & $\begin{array}{l}\text { Whole-bone stiffness measures } \\
\text { the amount of elastic deforma- } \\
\text { tion a structure undergoes when } \\
\text { loaded. }\end{array}$ \\
\hline & Work-to-fracture & $\mathrm{U}$ & $\mathrm{Nmm}$ & $\begin{array}{l}\text { The work-to-fracture is rep- } \\
\text { resented as the area under the } \\
\text { load-displacement curve. }\end{array}$ \\
\hline \multirow{5}{*}{$\begin{array}{l}\text { Tissue-level } \\
\text { mechanical } \\
\text { properties }\end{array}$} & Stress & $\sigma$ & $\mathrm{N} / \mathrm{mm}^{2}=\mathrm{MPa}$ & The force per unit area. \\
\hline & Strain & $\varepsilon$ & & $\begin{array}{l}\text { It is the relative deformation or } \\
\text { change in the length. }\end{array}$ \\
\hline & Ultimate strength & $\boldsymbol{\sigma}_{\mathrm{u}}$ & $\mathrm{N} / \mathrm{mm} 2=\mathrm{MPa}$ & $\begin{array}{l}\text { The highest stress on the surface } \\
\text { of the flexed bone. }\end{array}$ \\
\hline & Elastic modulus & $\mathrm{E}$ & $\mathrm{N} / \mathrm{mm}^{2}=\mathrm{MPa}$ & $\begin{array}{l}\text { The slope of the stress }(\sigma) \text { and } \\
\text { strain }(\varepsilon) \text { curve. }\end{array}$ \\
\hline & Toughness & $\mathrm{u}$ & $\mathrm{N} / \mathrm{mm}^{2}=\mathrm{MPa}$ & $\begin{array}{l}\text { The energy needed to fracture } \\
\text { the bone. }\end{array}$ \\
\hline
\end{tabular}

Shear test is suitable for any bone regardless of its geometry (45), so it was recommended by Harner \& Wilson (30) for poultry bones because of their diverse diaphyseal geometry.

\section{Torsional test}

It is preferable for torsional testing of whole bone, to pot the epiphyses in some suitable material in blocks of various shapes or to use clamps to grasp the bone properly inside the testing machine. A rotational force is applied to one of these 
ends while the other is fixed in position and force and angular deformation are recorded (36).

Harner \& Wilson (30) preferred torsional test to evaluate the fracture mode of the radius and the tibia of laying hen only as these were the only bones in chicken which have a straight diaphysis with uniform cross sections. It is applicable to symmetrical and straight bones only According to them, irregularity of ulna, humerus and femur was comparatively more.

\section{Tensile testing}

It is one of the most accurate technique for assessing bone properties but size of specimen should be large. The test specimen should be chosen as straight and even as possible. The bone sample is clamped between fixed load cell and a movable crosshead. The load and displacement are recorded (36).

\section{Compressive testing}

It is another popular tecnique for testing of the bones, and advantegeous particularly for spongy bone as small specimens can be used. Compression tests are performed on cubical or cylinderical shape bone specimen. After positioning a sample, it is compressed until the breaking point. However, these have less accuracy than tensile tests due to friction and probability of dearrangement on face of bone towards load (64) used lateral, central and medial compression to study mechanical properties of cancellous tibial bone of broiler birds and small crosshead speed of $0.5 \mathrm{~mm} / \mathrm{min}$. was chosen to avoid viscoelastic influences.

\section{Testing parameters}

After any biomechanical test application on bone, loaddisplacement curve is obtained. Data derived from loaddisplacement curves when testing whole bones are used to describe structural properties, like displacement, limit of elasticity/ yield point, ultimate/maximum force (Fmax), stiffness and the work of failure. The stiffness is calculated from the slope of the load-displacement curve before fracture occurs and it is important for the bone's function. The work to failure is area under the load-displacement curve. If ultimate force and stiffness are normalised to the bone's size, the resulting variables (ultimate stress and elastic modulus) then describe material properties of the bone, independent of its size. Toughness is also calculated from work to failure. For more detailed information, $(32,36,58)$ studies are available.

Parameters which can be obtained after mechanical testing of the bones $(14,32,58,65,66)$ are explained in Table 1.

\section{CONCLUSION}

The application of reliable methods to understand skeletal integrity is important for control of skeletal disorders. This review article is an effort to compile almost all biomechanical studies to investigate poultry bone properties. There is still uncertainity about the best suited bone for any of the test but further research is required in this field to avoid discrepancies. It is a well-known fact that mechanical properties of a bone depends on the testing method, its length, geometrical shape and the level of mineralisation. Different skeletal sites can produce variations in the calculation of the bone's material properties. There are still no ideal specimens for all the biomechanical testing, mainly due to their different shapes and sizes. Moreover, the advent of modern imaging techniques is gaining preferance day by day but we should still focus on direct measurement methods to get true information about the strength of the bones.

\section{DECLARATIONS}

\section{Ethics Approval}

Not applicable.

\section{Conflict of Interest}

The authors declare that they have no competing interests.

\section{Author Contribution}

Idea, concept and design: K. Khan, F. Sevil Kilimci, ME. Kara

Data collection and analysis: K. Khan, F. Sevil Kilimci, ME. Kara

Drafting of the manuscript: K. Khan, F. Sevil Kilimci, ME. Kara

Critical review: K. Khan, F. Sevil Kilimci, ME. Kara

\section{Data Availability}

The data that support the findings of this study are available from the corresponding author upon reasonable request.

\section{REFERENCES}

1. Korver D, Saunders-Blades J, Nadeau K. Assessing bone mineral density in vivo: Quantitative computed tomography. Poult Sci J. 2004; 2(83): 222-29.

2. Konig HE, Korbel R, Liebich H-G, Klupiec C. Avian anatomy: textbook and colour atlas. 3rd ed. $5 \mathrm{~m}$ Books Ltd; 2016. p. 64-80.

3. Watanabe J. Ontogeny of macroscopic morphology of limb bones in modern aquatic birds and their implications for ontogenetic ageing. Contribuciones del MACN. 2017; 7): 183 20 .

4. Church LE, Johnson LC. Growth of long bones in the chicken. Rates of growth in length and diameter of the humerus, tibia, and metatarsus. Am J Anat. 1964; 3(114): 521 38.

5. Dumont ER. Bone density and the lightweight skeletons of birds. Proc R Soc Lond B Biol Sci. 2010; 1691(277): 219398.

6. Bradshaw R, Kirkden R, Broom D. A review of the aetiology and pathology of leg weakness in broilers in relation to welfare. Avian Biol Res. 2002; 2(13): 45-04.

7. Kestin S, Knowles T, Tinch A, Gregory N. Prevalence of leg weakness in broiler chickens and its relationship with genotype. Vet Rec. 1992; 9(131): 190-94.

8. Knowles TG, Kestin SC, Haslam SM, Brown SN, Green LE, Butterworth A, et al. Leg disorders in broiler chickens: prevalence, risk factors and prevention. PLoS One 2008; 2(3): 
e1545.

9. Zhang B, Coon $\mathrm{CN}$. The relationship of various tibia bone measurements in hens. Poult Sci J. 1997; 12(76): 1698-01.

10. Süzer B, Tüfekçi K, Arican I, Petek M, Abdourhamane IM, Özbek M, et al. Effects of genotype and housing system on some bone biomechanical characteristics in broiler chickens. Vet Fak Derg. 2019; 3(66): 237-46.

11. Harlander-Matauschek A, Rodenburg T, Sandilands V, Tobalske B, Toscano MJ. Causes of keel bone damage and their solutions in laying hens. Worlds Poult Sci J. 2015; 3(71): 461-72.

12. Tauson R, Abrahamsson P. Foot and skeletal disorders in laying hens: Effects of perch design, hybrid, housing system and stocking density. Acta Agric Scand A Anim Sci. 1994; 2(44): 110-19.

13. Casinos A, Cubo J. Avian long bones, flight and bipedalism. Comp Biochem Physiol A Mol Integr Physiol. 2001; 1(131): 159-67.

14. Štofaníková J, Šály J, Molnár L, Sesztáková E, Vrabec V. The mechanical properties of broiler chicken bones affected by different dietary zinc levels. Afr J Biotechnol. 2012; 20(11): 4681-86.

15. Rath N, Huff G, Huff W, Balog J. Factors regulating bone maturity and strength in poultry. Poult Sci J. 2000; 7(79): 1024-32.

16. Ammann P, Robin B, Rizzoli R. Long-term exposure to strontium ranelate dose-dependently increases intrinsic bone quality. J Bone Miner Res. 2003, pp. S276.

17. Reichmann K, Connor J. Influence of dietary calcium and phosphorus on metabolism and production in laying hens. Br Poult Sci. 1977; 6(18): 633-40.

18. Aguado E, Pascaretti-Grizon F, Goyenvalle E, Audran $\mathrm{M}$, Chappard D. Bone mass and bone quality are altered by hypoactivity in the chicken. PLoS One. 2015; 1(10): e0116763.

19. Canello S, Gasparini G, Luisetto P, Di Cerbo A, Pomerri F. Bone computed tomography mineral content evaluation in chickens: effects of substances in homeopathic concentration. Homeopathy. 2016; 1(105): 92-95.

20. Charuta A, Cooper R. Computed tomographic and densitometric analysis of tibiotarsal bone mineral density and content in postnatal Peking ducks (Anas platyrhynchos var. domestica) as influenced by age and sex. Pol J Vet Sci. 2012; $3(15)$.

21. Dirrigl F, Dalsky G, Warner S. Dual $\square$ energy x $\square$ ray absorptiometry of birds: an examination of excised skeletal specimens. J Vet Med A. 2004; 6(51): 313-19.

22. Fleming R, Korver D, McCormack H, Whitehead C. Assessing bone mineral density in vivo: digitized fluoroscopy and ultrasound. Poult Sci J. 2004; 2(83): 207-14.
23. Fleming R, McCormack H, Whitehead C. Prediction of breaking strength in osteoporotic avian bone using digitized fluoroscopy, a low cost radiographic technique. Calcif Tissue Int. 2000; 4(67): 309-13.

24. Hester P, Schreiweis M, Orban J, Mazzuco H, Kopka M, Ledur $\mathrm{M}$, et al. Assessing bone mineral density in vivo: dual energy X-ray absorptiometry. Poult Sci J. 2004; 2(83): 215-21.

25. Kerschnitzki M, Zander T, Zaslansky P, Fratzl P, Shahar $\mathrm{R}$, Wagermaier W. Rapid alterations of avian medullary bone material during the daily egg-laying cycle. Bone. 2014; (69): $109-17$.

26. Schreiweis M, Orban J, Ledur M, Moody D, Hester P. Validation of dual-energy X-ray absorptiometry in live White Leghorns. Poult Sci J. 2005; 1(84): 91-99.

27. Sparke A, Sims T, Avery N, Bailey A, Fleming R, Whitehead C. Differences in composition of avian bone collagen following genetic selection for resistance to osteoporosis. Br Poult Sci. 2002; 1(43): 127-34.

28. Talaty P, Katanbaf M, Hester P. Life cycle changes in bone mineralization and bone size traits of commercial broilers. Poult Sci J. 2009; 5(88): 1070-77.

29. Neijat M, Casey-Trott T, Robinson S, Widowski T, Kiarie E. Effects of rearing and adult laying housing systems on medullary, pneumatic and radius bone attributes in 73 -wk old Lohmann LSL lite hens. Poult Sci J. 2019; 7(98): 2840-45.

30. Harner JP, Wilson JH. Testing techniques for determination of poultry bone strength. Trans ASAE. 1986; 2(29): 642-44.

31. Steiner M, Volkheimer D, Meyers N, Wehner T, Wilke H-J, Claes L, et al. Comparison between different methods for biomechanical assessment of ex vivo fracture callus stiffness in small animal bone healing studies. PLoS One. 2015; 3(10): e0119603.

32. Turner $\mathrm{CH}$, Burr DB. Basic biomechanical measurements of bone: a tutorial. Bone. 1993; 4(14): 595-08.

33. Kim W, Bloomfield S, Sugiyama T, Ricke S. Concepts and methods for understanding bone metabolism in laying hens. Worlds Poult Sci J. 2012; 1(68): 71-82.

34. Turner C. Biomechanics of bone: determinants of skeletal fragility and bone quality. Osteoporos Int. 2002; 2(13): 97-04.

35. Massé PG, Boskey AL, Ziv I, Hauschka P, Donovan SM, Howell DS, et al. Chemical and biomechanical characterization of hyperhomocysteinemic bone disease in an animal model. BMC Musculoskelet Disord. 2003; 1(4): 1-10.

36. An YH, Draughn RA. Mechanical testing of bone and the bone-implant interface. CRC press; 1999. p. 175-19.

37. Hossain MA, Islam AF, Iji P. Growth responses, excreta quality, nutrient digestibility, bone development and meat yield traits of broiler chickens fed vegetable or animal protein diets. 
S Afr J Anim Sci. 2013; 2(43): 208-18.

38. Diefenbeck M, Mückley T, Zankovych S, Bossert J, Jandt KD, Schrader C, et al. Freezing of rat tibiae at-20 c does not affect the mechanical properties of intramedullary bone/ implant-interface: brief report. Open J Orthop. 2011; 5): 219.

39. Linde F, Sørensen HCF. The effect of different storage methods on the mechanical properties of trabecular bone. J Biomech. 1993; 10(26): 1249-52.

40. Vaughan PE, Orth MW, Haut RC, Karcher DM. A method of determining bending properties of poultry long bones using beam analysis and micro-CT data. Poult Sci J. 2016; 1(95): 207-12.

41. Furman B, Saha S. Torsional testing of bone. Mechanical Testing of Bone and the Bone-Implant Interface (ed. YH An and RA Draughn). 2000; 219-39.

42. Ho KWK, Gilbody J, Jameson T, Miles AW. The effect of $4 \mathrm{~mm}$ bicortical drill hole defect on bone strength in a pig femur model. Arch Orthop Trauma Surg. 2010; 6(130): 79702 .

43. Lewis P, Danisman R, Gous R. Photoperiodic responses of broilers. III. Tibial breaking strength and ash content. Br Poult Sci. 2009; 6(50): 673-79.

44. Toscano MJ, Nasr M, Hothersall B. Correlation between broiler lameness and anatomical measurements of bone using radiographical projections with assessments of consistency across and within radiographs. Poult Sci J. 2013; 9(92): 2251 58.

45. Standarts A. Shear and three-point bending test of animal bone. ANSI/ASAE S459 DEC01, USA. 2003.

46. Duggan BM, Hocking PM, Schwarz T, Clements DN. Differences in hindlimb morphology of ducks and chickens: effects of domestication and selection. Genet Sel Evol. 2015; 1(47): 1-13.

47. Williams B, Waddington D, Murray D, Farquharson C. Bone strength during growth: influence of growth rate on cortical porosity and mineralization. Calcif Tissue Int. 2004; 3(74): 236-45.

48. Judex S, Lei X, Han D, Rubin C. Low-magnitude mechanical signals that stimulate bone formation in the ovariectomized rat are dependent on the applied frequency but not on the strain magnitude. J Biomech. 2007; 6(40): 1333-39.

49. Lane NE, Yao W, Balooch M, Nalla RK, Balooch G, Habelitz S, et al. Glucocorticoid $\square$ treated mice have localized changes in trabecular bone material properties and osteocyte lacunar size that are not observed in placebo $\square$ treated or estrogen $\square$ deficient mice. J Bone Miner Res. 2006; 3(21): 46676.

50. Robling AG, Burr DB, Turner CH. Recovery periods restore mechanosensitivity to dynamically loaded bone. J Exp Biol. 2001; 19(204): 3389-99.
51. Rubin CT, Lanyon LE. Regulation of bone mass by mechanical strain magnitude. Calcif Tissue Int. 1985; 4(37): 411-17.

52. Warden SJ, Hurst JA, Sanders MS, Turner CH, Burr $\mathrm{DB}, \mathrm{Li}$ J. Bone adaptation to a mechanical loading program significantly increases skeletal fatigue resistance. J Bone Miner Res. 2005; 5(20): 809-16.

53. Kim W, Donalson L, Herrera P, Woodward C, Kubena L, Nisbet D, et al. Research note: Effects of different bone preparation methods (fresh, dry, and fat-free dry) on bone parameters and the correlations between bone breaking strength and the other bone parameters. Poult Sci J. 2004; 10(83): 1663-66.

54. Gebhardt-Henrich SG, Pfulg A, Fröhlich EK, Käppeli S, Guggisberg D, Liesegang A, et al. Limited associations between keel bone damage and bone properties measured with computer tomography, three-point bending test, and analysis of minerals in Swiss laying hens. Front Vet Sci. 2017; 4): 128.

55. Tatara MR, Krupski W, Kozłowski K, Drażbo A, Jankowski J. Effects of administration of four different doses of Escherichia coli phytase on femur properties of 16-weekold turkeys. BMC Vet Res. 2015; 1(11): 69.

56. Shim M, Karnuah A, Mitchell A, Anthony N, Pesti G, Aggrey S. The effects of growth rate on leg morphology and tibia breaking strength, mineral density, mineral content, and bone ash in broilers. Poult Sci J. 2012; 8(91): 1790-95.

57. Vitorović D, Pavlovski Z, Škrbić Z, Lukić M, Petričević V, Adamović ID. Morphometric and mechanical characteristics of leg bones in autochtonous naked neck breeds of chickens in Serbia. Biotechnology in Animal Husbandry. 2009; 5-62(25): 1033-38.

58. Cowin SC. Bone mechanics handbook, CRC press. 2001.

59. Karásek F, Štenclová H, Št’astník O, Mrkvicová E, Pavlata L, Nedomová S, et al. The effect of calcium and magnesium supplementation on performance and bone strength of broiler chickens. Potravinárstvo: Slovak Journal of Food Sciences. 2017; 1(11): 120-25.

60. Rowland Jr L, Harms R. The effect of wire pens, floor pens and cages on bone characteristics of laying hens. Poult Sci J. 1970; 5(49): 1223-25.

61. Liu D, Veit H, Wilson J, Denbow D. Long-term supplementation of various dietary lipids alters bone mineral content, mechanical properties and histological characteristics of Japanese quail. Poult Sci J. 2003; 5(82): 831-39.

62. Wilson J, Ruszler P. Effects of dietary boron on poultry bone strength. Trans ASAE. 1995; 1(38): 167-70.

63. Buijs S, Van Poucke E, Van Dongen S, Lens L, Baert J, Tuyttens FA. The influence of stocking density on broiler chicken bone quality and fluctuating asymmetry. Poult Sci J. 2012; 8(91): 1759-67.

64. Capps SG. Effect of tibial dyschondroplasia on broiler 
growth and cancellous bone mechanical properties. Avian Dis. 1998; 162-67.

65. Sevil-Kilimci F, Kara ME. Kemiklerin Mekanik Özelliklerinin Değerlendirilmesinde Kullanılan Temel Biyomekanik Kavramlar. Animal Health Production and Hygiene. 2013; 2(2): 235-39.

66. Jepsen KJ, Silva MJ, Vashishth D, Guo XE, Van Der Meulen MC. Establishing biomechanical mechanisms in mouse models: practical guidelines for systematically evaluating phenotypic changes in the diaphyses of long bones. J Bone Miner Res. 2015; 30(6), 951-66. 